\title{
Adoption of modern beekeeping and its impact on honey production in the former Mwingi District of Kenya: assessment using theory-based impact evaluation approach
}

\author{
Hippolyte D. Affognon*, W.S. Kingori, A.I. Omondi, \\ M.G. Diiro, B.W. Muriithi, S. Makau and S.K. Raina \\ International Centre of Insect Physiology and Ecology (icipe), \\ PO Box 30772-00100, Nairobi, Kenya
}

(Accepted 23 April 2015)

\begin{abstract}
This study used the theory-based impact evaluation approach to understand as to how promotion of beekeeping by the Commercial Insects Programme (CIP) of the International Centre of Insect Physiology and Ecology (icipe) has had an impact on honey production in the former Mwingi District of Kenya (now merged into Kitui County). We examined the adoption of modern hives promoted by icipe and applied data envelopment analysis (DEA) to assess the technical efficiency (TE) of participants in CIP. CIP participants had an average TE of 0.56, which was significantly higher than that of non-participants in the former Kitui District (average TE of 0.26). Those who adopted modern hives achieved the highest average levels of TE (0.59). The study fits a Probit model to identify the drivers of adoption and a Tobit model to assess the intensity of adoption of modern hives. The propensity score matching approach was used to evaluate the impact of modern hives on honey production. Results indicate that perceptions about the yield and quality of honey obtained from modern hives significantly increased beekeepers' adoption decisions. The intensity of adoption expressed as the proportion of modern hives owned by beekeepers was significantly high among farmers who participated in CIP. A positive and significant relationship was observed between the adoption of modern hives and the quantity of honey produced. The present study indicates, through the average TE, that considerable room still exists for the improvement of beekeeping and provides strong evidence for scaling up the dissemination of modern hives in areas of Kenya with high potential.
\end{abstract}

Key words: participation, adoption, modern beehives, technical efficiency, honey production, Kenya

\section{Introduction}

Beekeeping in Kenya is mainly practised in environments where opportunities for agricultural cropping are limited and the natural vegetation is made up of many species of plants suitable for bees to forage on (Nightingale, 1976). Traditional beekeeping has a long history in Kenya with a

*E-mail: haffognon@icipe.org variety of practices noted (Nightingale and Crane, 1983). Beekeeping with modern hives is relatively new, having been introduced by the colonial government in the 1950s and further promoted by government and other development organizations after independence. Consequently, two broad systems, extensive and intensive, are practised (Carroll and Kinsella, 2013). Extensive systems are typical of traditional beekeeping methods, using mostly traditional log hives that are usually hung 
high in trees, scattered over large areas away from people and animals. This system is practised mainly in the arid and semi-arid lands of Kenya. In intensive systems, bees are kept mostly in top bar or frame hives (modern hives) on small- to mediumscale farms in agriculturally productive parts of the country where the majority of people live (Carroll and Kinsella, 2013). Beekeeping is an important alternative source of livelihood for many resourcepoor farmers, but despite the favourable natural environment and the potential for establishing sustainable livelihoods in rural areas, it often lacks the necessary financial and technological support required to exploit fully its great potential in conserving forests and natural ecosystems and reducing poverty. Compared with other agricultural enterprises, beekeeping is a low-cost venture with the potential to have tremendous impact in improving household livelihoods and the national economy. Opportunities in both domestic and export markets exist. However, inefficient technologies, insufficient knowledge, environmental degradation and low production are some of the key challenges facing the sub-sector (Jiwa, 2005; Muga, 2011). To promote beekeeping as an alternative source of income generation, the International Centre of Insect Physiology and Ecology (icipe) and the United Nations Development Programme (UNDP), under the Commercial Insects Programme (CIP), introduced modern hives (Kenya top bar hive and the Langstroth hive) in Mwingi District (which merged into Kitui County in 2010). The Programme, in collaboration with other partners such as the Kenyan Ministry of Livestock Development, the British High Commission and the International Fund for Agricultural Development (IFAD), constructed the Mwingi honey marketplace in 2002 to create outlets for beekeepers to help them attain self-sustainability in marketing their products. The package provided by CIP also included training and the processing, packaging and branding of products through certification. These interventions were expected to stimulate the adoption of modern beekeeping and improve productivity. The present study used theory-based methods of impact assessment to evaluate the effect of the CIP interventions by examining farmers' adoption of modern hives and the impact of their use on honey production in Mwingi (now merged into Kitui County of Kenya).

\section{Methods}

Theory-based impact evaluation

According to White (2009), theory-based evaluation, which examines the assumptions underlying the causal chain from inputs to outcomes and impact, is a well-established approach that has long been used in experimental and quasi-experimental situations as a way of explaining findings (Blackman and Reich, 2009). In a review of impact evaluation designs for a range of developmental interventions, Rogers (2009) noted that a theorybased approach would be appropriate in every case (White, 2009). In this study, we followed the review of outcomes to impact approach developed by the Global Environment Facility (GEF, 2009). An extended Theory of Change (TOC) approach was used to evaluate the performance of CIP through an in-depth analysis of the project's documentation to identify and then assess outputs that ultimately contribute to the achievement of outcomes and impacts (the improvement of honey production). This was coupled with the extensive collection of primary field data at the project site and in a control area of comparable ecological conditions. The TOC of CIP encompassed the entire result chain and consisted of a set of activities (training of beekeepers in modern techniques and enterprise development skills, and establishing and equipping a honey marketplace in Mwingi). These were designed to deliver certain defined outputs (many beekeepers were trained, marketplace was established and is functional, and many were trained on honey processing, packaging and marketing). In turn, these outputs aimed to make a significant contribution to the achievement of a set of outcomes (knowledge improved and translated into the improvement of technical efficiency (TE)). Ultimately, the outcomes were expected to result in a set of long-term impacts from the project (increased production of quality honey leading to the improvement of beekeepers' livelihoods) (GEF, 2009). This analysis of activities, outputs, outcomes and impact pathways helps the logic that CIP has employed to work towards the achievement of improvement in honey production.

\section{Primary field data collection and analysis}

The study is based on a quasi-experimental cross-sectional survey of beekeeping farmers conducted in 2013 in CIP implementation areas in the present Kitui County. As a control, data gathered from the non-CIP beekeepers in the former Kitui District (an area where ecological conditions are comparable to those in the former Mwingi District) were analysed to draw useful inferences about the impact and performance of beekeeping farms under CIP interventions. A total of 569 participants (238 CIP and 331 non-CIP) were randomly selected from the actual former district areas. This sample size was sufficiently large to represent the households of interest in the study area. Using data envelopment analysis (DEA), we assessed the TE gains from 
participation in CIP among the farm households as the precondition for improvement in honey production. The TE relates to the degree to which a farmer produces the maximum feasible outputs from a given bundle of inputs, or uses a minimum feasible amount of inputs to produce a given level of outputs (Farrell, 1957; Coelli et al., 2005). We constructed the DEA model assuming that each beekeeping farm produces a quantity of output $Y_{\mathrm{i}}$ using multiple inputs $X_{\mathrm{i}}$, and each farm $(i)$ is allowed to set its own set of weights for both inputs and outputs. Subsequently, a Probit model was fitted to explore the determinants of the likelihood of adoption and a two-limit Tobit model to assess the intensity of adoption of modern hives (Adesina and Baidu-Forson, 1995). Propensity score matching was, in addition, used to assess the impact of the adoption of modern hives on honey production (Rosenbaum and Rubin, 1983).

\section{Results and Discussion}

\section{Socio-economic characteristics of beekeepers}

The socio-economic characteristics of beekeepers disaggregated by participation or nonparticipation in the CIP are summarized in Table 1. From these results, participants in CIP were significantly older than non-participants but within the productive and economically active age groups. Carroll and Kinsella (2013) found that beekeepers in Kenya who adopted new technologies tended to be, on average, older than the general population and more economically endowed with significantly higher incomes. They had lower total numbers of hives, yet produced much more honey and had more hives in production than those not participating. In our research, the comparison of both groups showed that the participant and non-participant beekeepers differed significantly with respect to gender, education attainment, off-farm income and number of apiary visits.

\section{Beekeeping technical efficiency}

The summary statistics of the variables used in the DEA model are presented in Table 2. On average, beekeeping households owned 18 hives and produced $70 \mathrm{~kg}$ of honey per harvest. However, farmers who did not participate in CIP activities had a significantly higher number of hives but a significantly lower production level per harvest than CIP adopters who spent significantly more money in terms of operating costs. Relatively few farmers produced other beekeeping products such as wax, combs, and propolis.

The mean TE of beekeeping farms in the former Mwingi District (participating in CIP) and in the former Kitui District (not participating in CIP) is shown in Table 3. From the results, it is evident that beekeepers that used modern hives (mixed with traditional hives) and were participants in CIP had the highest mean TE. The results indicate that there was a highly significant difference between the TE of adopters and non-adopters $(t=-11.54$; $\mathrm{df}=567 ; P<0.01)$. Similarly, there was a highly significant difference between the TE of those that used only traditional hives and beekeepers who used a mix of traditional and modern hives $(t=-7.80 ; \mathrm{df}=567, P<0.01)$.

Table 1. Socio-economic characteristics (mean \pm standard error) of CIP participating and non-participating beekeepers in Kitui County, Kenya

\begin{tabular}{|c|c|c|c|c|}
\hline Socio-economic characteristics & $\begin{array}{c}\text { Total } \\
(n=569)\end{array}$ & $\begin{array}{l}\text { Non-participants } \\
\quad(n=331)\end{array}$ & $\begin{array}{l}\text { Participants } \\
\quad(n=238)\end{array}$ & $\begin{array}{c}t \text {-test } \\
(\mathrm{df}=567)\end{array}$ \\
\hline Age of the household head & $51.0 \pm 0.6$ & $48.4 \pm 0.8$ & $54.7 \pm 0.9$ & $-5.13^{* * *}$ \\
\hline Household head education (no. of years) & $5.79 \pm 0.17$ & $6.4 \pm 0.2$ & $4.9 \pm 0.3$ & $4.76^{* * *}$ \\
\hline No. of active persons in the household & $3.82 \pm 0.10$ & $3.8 \pm 0.1$ & $4.0 \pm 0.1$ & -0.60 \\
\hline Dependency ratio & $1.1 \pm 0.0$ & $1.1 \pm 0.1$ & $1.1 \pm 0.1$ & 0.75 \\
\hline Off-farm income (dummy $1=$ Yes, $0=\mathrm{No}$ ) & $0.24 \pm 0.02$ & $0.14 \pm 0.02$ & $0.37 \pm 0.03$ & $-6.86^{* * *}$ \\
\hline Access to credit (dummy $1=$ Yes, $0=\mathrm{No}$ ) & $0.01 \pm 0.00$ & $0.01 \pm 0.00$ & $0.00 \pm 0.00$ & 0.30 \\
\hline Years of beekeeping experience & $19.3 \pm 0.5$ & $19.8 \pm 0.7$ & $18.6 \pm 0.8$ & 1.08 \\
\hline No. of acres ${ }^{+}$of land owned and rented under cultivation & $5.1 \pm 0.3$ & $5.6 \pm 0.6$ & $4.5 \pm 0.2$ & 1.49 \\
\hline Total household livestock holding in TLU & $3.87 \pm 0.15$ & $4.0 \pm 0.2$ & $3.7 \pm 0.2$ & 0.95 \\
\hline Average household income estimate (US\$) & $86.7 \pm 4.0$ & $72.2 \pm 4.7$ & $106.8 \pm 6.7$ & $-4.37^{* * *}$ \\
\hline Yield perception (dummy $1=$ High, $0=$ Low) & $0.24 \pm 0.02$ & $0.04 \pm 0.01$ & $0.5 \pm 0.04$ & $-15.49^{* * *}$ \\
\hline Quality perception (dummy $1=$ High, $0=$ Low) & $0.4 \pm 0.02$ & $0.1 \pm 0.02$ & $0.8 \pm 0.03$ & $-25.54^{* * *}$ \\
\hline Skills needed perception (dummy $1=$ High, $0=$ Low) & $0.34 \pm 0.02$ & $0.04 \pm 0.01$ & $0.8 \pm 0.03$ & $-27.67^{* * *}$ \\
\hline
\end{tabular}

TLU, tropical livestock unit.

+1 acre $=0.4$ ha.

*** Significant at $99 \%$ confidence level. 
Table 2. Summary statistics (mean \pm standard error) of variables used in the DEA Model, by CIP participation in Kitui County, Kenya

\begin{tabular}{|c|c|c|c|c|}
\hline Variable & $\begin{array}{c}\text { Total } \\
(n=569)\end{array}$ & $\begin{array}{l}\text { CIP participants } \\
\quad(n=238)\end{array}$ & $\begin{array}{l}\text { CIP non-participants } \\
(n=331)\end{array}$ & $\begin{array}{c}t \text {-test } \\
(\mathrm{df}=567)\end{array}$ \\
\hline Quantity of honey produced per harvest $(\mathrm{kg})^{1}$ & $70.3 \pm 5.4$ & $118.1 \pm 11.5$ & $35.9 \pm 3.3$ & $-7.82^{* * *}$ \\
\hline Quantity of wax produced $(\mathrm{kg})$ & $1.8 \pm 0.5$ & $2.3 \pm 0.3$ & $1.4 \pm 0.8$ & -0.94 \\
\hline Quantity of combs produced (kg) & $0.06 \pm 0.04$ & $0.02 \pm 0.02$ & $0.1 \pm 0.1$ & 0.86 \\
\hline Quantity of propolis produced (kg) & $0.11 \pm 0.03$ & $0.25 \pm 0.1$ & $0.01 \pm 0.01$ & $-3.46^{* * *}$ \\
\hline Total number of hives owned by the households & $17.6 \pm 1.2$ & $13.6 \pm 1.2$ & $20.5 \pm 2.0$ & $2.72^{* * *}$ \\
\hline Start-up cost (US\$) & $218.6 \pm 11.4$ & $228.9 \pm 17.4$ & $204.2 \pm 12.4$ & 1.07 \\
\hline Annual labour (in man-days) & $21.4 \pm 2.3$ & $24.8 \pm 5.0$ & $19.0 \pm 1.7$ & -1.23 \\
\hline Annual feed costs (operating costs US\$) ${ }^{2}$ & $762.9 \pm 59.9$ & $1726.2 \pm 111.8$ & $70.2 \pm 26.3$ & $-16.6^{* * *}$ \\
\hline
\end{tabular}

${ }^{1}$ Farmers harvest twice a year, on average, that is, once a season with two seasons a year.

${ }^{2} 1 \mathrm{US} \$=$ KES 85 at the time of the survey.

*** Significant at $99 \%$ confidence level.

The implication is that both participation in CIP and the use of modern hives have a positive effect on efficiency in honey production. However, participation in CIP does not imply the exclusive use of modern hives. For instance, 36 of CIP participants were traditional producers (used only traditional hives), while the rest (64\%) used a mix of modern and traditional hives. Thus, the relatively higher TE by CIP participants engaged in improved beekeeping was not derived exclusively from their ownership of modern hives. Consequently, the results present evidence that the observed positive impact on farmers' efficiency could be attributed to other components of CIP (for instance, capacity building), in addition to modern hives, and the other characteristics of the farms or farmers.

\section{Determinants of adoption and the intensity of adoption of modern beehives}

The results of the Probit model of factors that influence adoption and the two-limit Tobit model for the intensity of adoption of modern hives are presented in Table 4. Education of the household head had a positive association with adoption and the intensity of adoption. This implies that households with more years of education are more likely to have access to information and are therefore amenable to the acceptance of new practices (Abebe et al., 2008; Akudugu et al., 2012). In addition, the level of adoption increased with exposure through apiary visits. The findings underscore the need to increase awareness and leverage interventions on improved technology to promote the level of adoption as also shown by results of other studies (Nnadi and Akwiwu 2008; Abebe 2008; Ouma and De Groote, 2011; Martey et al., 2013). However, the estimated household monthly income had a negative and significant effect on the probability of adoption, suggesting that farmers with high incomes are less likely to adopt the improved technology. This is because in the region covered by $\mathrm{CIP}$, beekeeping is associated with the resource poor, and thus could play a strategic role in poverty alleviation. Participation in CIP had a positive and significant effect on the probability of adoption but no influence on the intensity of adoption. Beekeepers were likely to participate in CIP since it would enhance the probability of acquiring the improved technology either directly through skill development and material acquisition or indirectly through linkages to financial service providers (Doss et al., 2003; Cramb 2003; Abebe et al., 2008). It was found that farmers' perceptions of technology-specific characteristics significantly explained both the adoption decision and the intensity of

Table 3. Technical efficiency of beekeeping farms in the former Mwingi District now merged into Kitui County, Kenya (participating in the Commercial Insects Programme (CIP)) and in the former Kitui District (not participating in CIP)

\begin{tabular}{|c|c|c|c|}
\hline Farm category & & $\begin{array}{l}\text { Technical } \\
\text { efficiency }\end{array}$ & $\begin{array}{c}t \text {-test } \\
(\mathrm{df}=567)\end{array}$ \\
\hline \multirow[t]{2}{*}{ Participation in CIP } & Participants $(n=238)$ & 0.56 & \multirow[t]{2}{*}{$-11.54^{* * *}$} \\
\hline & Non-participants $(n=331)$ & 0.26 & \\
\hline \multirow[t]{2}{*}{ Type of beekeeping } & Traditional (using exclusively traditional hives) $(n=408)$ & 0.35 & \multirow[t]{3}{*}{$-7.80^{* * *}$} \\
\hline & Improved (using both traditional and modern hives) $(n=161)$ & 0.59 & \\
\hline All farmers $(n=569)$ & & 0.35 & \\
\hline
\end{tabular}

*** Significant at $99 \%$ confidence level. 
Table 4. Determinants of adoption and the intensity of adoption of modern beehives in the former Mwingi District (now merged into Kitui County) and in the former Kitui District of Kenya

\begin{tabular}{|c|c|c|c|c|c|}
\hline & \multicolumn{3}{|c|}{ Adoption (Probit model) } & \multicolumn{2}{|c|}{$\begin{array}{l}\text { Intensity of adoption } \\
\text { (two-limit Tobit model) }\end{array}$} \\
\hline & $\begin{array}{l}\text { Coefficient } \pm \text { standard } \\
\text { error }\end{array}$ & Z & $P>|Z|$ & $\begin{array}{c}\text { Coefficient } \pm \text { standard } \\
\text { error }\end{array}$ & $t$ value \\
\hline Gender of the household head & $0.2 \pm 0.3$ & 0.77 & 0.443 & $-0.05 \pm 0.1$ & -0.38 \\
\hline Age of the household head & $0.01 \pm 0.01$ & 0.91 & 0.363 & $0.0 \pm 0.0$ & 0.59 \\
\hline Years of schooling & $0.1 \pm 0.03$ & 2.56 & 0.010 & $0.04 \pm 0.02$ & 2.62 \\
\hline Dependency ratio & $0.03 \pm 0.05$ & 0.53 & 0.599 & $0.03 \pm 0.03$ & 1.29 \\
\hline Off-farm income & $0.2 \pm 0.2$ & 0.68 & 0.498 & $0.03 \pm 0.1$ & 0.23 \\
\hline Active population & $0.03 \pm 0.05$ & 0.58 & 0.561 & $-0.00 \pm 0.03$ & -0.55 \\
\hline Household monthly income (Kshs) & $-0.0 \pm 0.0$ & -1.89 & 0.059 & $-7.5 \mathrm{e}^{-06} \pm 9.8 \mathrm{e}^{-06}$ & -0.77 \\
\hline Livestock holding (TLU) & $-0.02 \pm 0.04$ & -0.53 & 0.595 & $-0.0 \pm 0.02$ & -0.08 \\
\hline Area under cultivation & $0.01 \pm 0.03$ & 0.55 & 0.581 & $-0.0 \pm 0.02$ & -0.26 \\
\hline Apiary visits & $1.2 \pm 0.3$ & 3.62 & 0.000 & $0.5 \pm 0.2$ & 2.76 \\
\hline CIP participation & $1.6 \pm 0.4$ & 4.43 & 0.000 & $0.1 \pm 0.2$ & 0.52 \\
\hline Yield perception & $1.6 \pm 0.3$ & 4.86 & 0.000 & 0.5479 & 2.91 \\
\hline Honey quality perception & $1.9 \pm 0.4$ & 4.81 & 0.000 & $1.4 \pm 0.3$ & 5.26 \\
\hline Skills needed perception & $-0.3 \pm 0.3$ & -1.01 & 0.314 & $0.12 \pm 0.2$ & 0.55 \\
\hline \multirow[t]{5}{*}{ Constant } & $-5.3 \pm 0.9$ & -5.70 & 0.000 & $-2.6 \pm 0.4$ & -5.99 \\
\hline & \multicolumn{3}{|c|}{ Number of observations $=565$} & \multicolumn{2}{|c|}{ Number of observations $=565$} \\
\hline & \multirow{2}{*}{\multicolumn{3}{|c|}{$\begin{array}{c}\mathrm{LR} \chi^{2}(14)=486.76 \\
P>\chi^{2}=0.0000\end{array}$}} & \multirow{2}{*}{\multicolumn{2}{|c|}{ LR $\chi^{2}(14)=332.17$}} \\
\hline & & & & & \\
\hline & \multicolumn{3}{|c|}{ Pseudo $R^{2}=0.7248$} & \multicolumn{2}{|c|}{ Pseudo $R^{2}=0.4135$} \\
\hline
\end{tabular}

TLU, tropical livestock unit; LR, likelihood ratio.

adoption. There was a positive and significant relationship between perceptions on honey yield and quality and the extent of adoption of modern hives. Previously, Adesina and Baidu-Forson (1995) and Wandji et al. (2012) also found that farmers' perceptions of technology characteristics significantly affected their decisions whether to adopt a technology or not.

\section{Impact of modern beehive adoption on honey production}

The impact analysis was preceded by a specification of the propensity scores for the treatment variables. The results (Table 5) indicate a highly significant difference between the yields of adopters and of non-adopters $(P<0.01)$. The effect of adoption on honey production was estimated using various matching models, as none were a priori superior to the others (Becker and Ichino, 2002). Various algorithms were tested and the nearest neighbour matching (without replacement) and caliper (0.01) (Smith and Todd, 2005) provided better matching with a $66 \%$ reduction in total bias, indicating a good level of covariate balancing (Rosenbaum and Rubin, 1983). Balancing test results indicated no significant $(P>0.05)$ differences in mean $P$-scores for adopter and non-adopter groups, implying that the treated group (adopters) and non-adopters are likely to have similar characteristics and fall in the region of common support (Heckman et al., 1997).

The average treatment effect on the treated (ATT), the statistic of interest, shows a significant difference in honey production between the adopters and non-adopters after controlling for hidden selection bias. The average yield gain due to adoption was approximately $40 \%$ and this indicates that adoption had a strong positive and significant effect on honey yield. The sensitivity analysis using Rosenbaum bounds approach indicates that the results are robust to the potential presence of hidden selection bias (Rosenbaum and Rubin, 1983). Therefore, the ATT estimates are the unbiased effect of the adoption of modern hives.

Table 5. Estimated impact on honey production, the average treatment effect on the treated group (ATT) in the former Mwingi District and in the former Kitui District (now merged into Kitui County) of Kenya

\begin{tabular}{lccr}
\hline & Treated & Control & Difference $^{+}$ \\
\hline Unmatched & 153.2 & 38.0 & $115.2 \pm 11.2^{* * *}$ \\
ATT after matching & 79.4 & 45.2 & $34.2 \pm 15.5^{* * *}$
\end{tabular}

${ }^{+}$Difference $=$mean \pm standard error.

$* * *$ Significant at $99 \%$ confidence level. 


\section{Conclusion}

The TOC approach articulates the assumptions about the process through which change in the honey yield has occurred. It specifies the way in which the intermediate outcome is related to the precondition to achieving the desired change. Participation in icipe's CIP has led to the improvement of TE in beekeeping, the adoption of the modern hives that CIP promoted, and a significant increase in honey production. The study provides evidence that supports the potential of beekeeping as a pathway out of poverty. Future interventions should therefore aim not only at scaling up CIP activities but also ensuring that the intervention focuses on socio-economic factors and technology characteristics that influence the adoption of modern hives.

\section{Acknowledgements}

The authors acknowledge the institutional and financial support of the International Centre of Insect Physiology and Ecology (icipe). They also thank Christopher Mutungi for his comments and English editing that helped improve the quality of the paper.

\section{References}

Abebe W., Puskur R. and Karippai R. (2008) Adopting Improved Box Hive in Atsbi Wemberta District of Eastern Zone, Tigray Region: Determinants and Financial Benefits (Improving Productivity and Market Success of Ethiopian Farmers, Project Working Paper 10). ILRI (International Livestock Research Institute), Nairobi, Kenya. 30 pp.

Adesina A. A. and Baidu-Forson J. (1995) Farmers' perceptions and adoption of new agricultural technology: evidence from analysis in Burkina Faso and Guinea, West Africa. Agricultural Economics 13, 1-9.

Akudugu M. A., Guo E. and Dadzie S. K. (2012) Adoption of modern agricultural production technologies by farm households in Ghana: what factors influence their decisions? Journal of Biology, Agriculture and Healthcare 2, 1-13.

Becker S. O. and Ichino A. (2002) Estimation of average treatment effects based on propensity scores. The Stata Journal 2, 358-377.

Blackman L. and Reich S. (2009) Randomized controlled trials: a gold standard with feet of clay? In What Counts as Credible Evidence in Applied Research and Evaluation Practice? (Edited by S. I. Donaldson, C. A. Christie and M. M. Mark) (Chapter 4). Sage Publications Inc., Thousand Oaks, California.

Carroll T. and Kinsella J. (2013) Livelihood improvement and smallholder beekeeping in Kenya: the unrealised potential. Development in Practice 23, 332-345. doi:10.1080/09614524.2013.781123.
Coelli T. J., Rao D. S. P., O’Donnell C. J. and Battese G. E. (2005) An Introduction to Efficiency and Productivity Analysis 2nd ed. Springer, New York, USA. 350 pp.

Cramb R. A. (2003) Processes affecting the successful adoption of new technologies by smallholders, pp. 11-22. In Working with Farmers: The Key to the Adoption of Forage Technologies (edited by B. Hacker). ACIAR Proceedings No. 95. Australian Centre for International Agricultural Research, Canberra.

Doss C., Mwangi W., Verkuijl H. and de Groote H. (2003) Adoption of Maize and Wheat Technologies in Eastern Africa: A Synthesis of the Findings of 22 Case Studies. CIMMYT Economics Working Paper 03-01. CIMMYT, Mexico, D.F. 39 pp. Available at: http:/ /ageconsearch. umn.edu/bitstream/46522/2/wp030001.pdf.

Farrell M. J. (1957) The measurement of productive efficiency. Journal of the Royal Statistical Society 120, 253-290.

GEF [Global Environment Facility] (2009) ROtl Handbook: Towards Enhancing the Impacts of Environmental Projects. Methodological Paper \#2. 46 pp. Available at: www.thegef.org/gef/sites/thegef.org/ files/documents/M2_ROtI\%20Handbook.pdf.

Heckman J. J., Ichimura H. and Todd P. E. (1997) Matching as an econometric evaluation estimator: evidence from evaluating a job training programme. The Review of Economic Studies 64, 605-654.

Jiwa F. (2005) Honey Care Africa's Tripartite Model: An Innovative Approach to Sustainable Beekeeping in Kenya. Available at: http://www.apimondia.com/apiacta/ slovenia/en/jiwa.pdf (accessed on 16 February 2015).

Martey E., Wiredu A. N., Asante B. O., Annin K., Dgobe W., Attoh C. and Al-Hassan R. M. (2013) Factors influencing participation in rice development projects: the case of smallholder rice farmers in northern Ghana. International Journal of Development and Economic Sustainability 1, 13-27.

Muga M. (2011) Formulating a Strategy for Production, Value Addition and Marketing of Products from Arid and Semi-arid Areas in the IGAD Region: The Case of Kenya (edited by S. J. Muchina Munyua and S. Mbiru). IGAD Consultancy Report, Djibouti.

Nightingale J. M. (1976) Traditional beekeeping among Kenya tribes, and methods proposed for improvement and modernization, pp. 15-22. In Apiculture in Tropical Climates (edited by E. Crane). International Bee Research Association, London.

Nightingale J. and Crane E. (1983) A Lifetime's Recollections of Kenya Tribal Beekeeping. International Bee Research Association, London. 74 pp.

Nnadi F. N. and Akwiwu C. D. (2008) Determinants of youth's participation in rural agriculture in Imo State, Nigeria. Journal of Applied Sciences 8, 328-333. doi:10.3923/jas.2008.328.333.

Ouma J. O. and De Groote H. (2011) Determinants of improved maize seed and fertilizer adoption in Kenya. Journal of Development and Agricultural Economics 3, 529-536. 
Rogers P. J. (2009) Matching impact evaluation design to the nature of the intervention and the purpose of the evaluation. Journal of Development Effectiveness 1, 217-226. doi:10.1080/19439340903114636.

Rosenbaum P. R. and Rubin D. B. (1983) Constructing a control group using multivariate matched sampling methods that incorporate the propensity score. The American Statistician 39, 33-38.

Smith J. A. and Todd P. E. (2005) Does matching overcome LaLonde's critique of nonexperimental estimators?
Journal of Econometrics 125, 305-353. doi:10.1016/ j.jeconom.2004.04.011.

Wandji D. N, Pouomogne V., Binam J. N. and Nouaga R. Y. (2012) Farmers' perception and adoption of new aquaculture technologies in the Western Highlands of Cameroon. Tropicultura 30, 180-184.

White H. (2009) Theory-Based Impact Evaluation: Principles and Practice. International Initiative for Impact Evaluation, Working Paper 3. International Initiative for Impact Evaluation (3ie), New Delhi. 20 pp. 